\title{
Effects of Magnesium Content on Structure and Electrochemical Properties of La-Mg-Pr-Al-Mn-Co-Ni Hydrogen Storage Alloys
}

\author{
L. M. C. Zarpelon, E. P. Banczek, L. G. Martinez, N. B. Lima, I. Costa, and R. N. Faria (iD \\ Center of Science and Materials Technology, Nuclear and Energy Research Institute (IPEN-CNEN/SP), São Paulo, SP, Brazil \\ Correspondence should be addressed to R. N. Faria; rfaria@ipen.br
}

Received 25 October 2017; Accepted 20 December 2017; Published 8 February 2018

Academic Editor: Jörg M. K. Wiezorek

Copyright $\odot 2018$ L. M. C. Zarpelon et al. This is an open access article distributed under the Creative Commons Attribution License, which permits unrestricted use, distribution, and reproduction in any medium, provided the original work is properly cited.

\begin{abstract}
The discharge capacity, microstructures, and corrosion resistance of some as-cast alloys represented by the formula $\mathrm{La}_{0.7-x} \mathrm{Mg}_{x} \mathrm{Pr}_{0.3} \mathrm{Al}_{0.3} \mathrm{Mn}_{0.4} \mathrm{Co}_{0.5} \mathrm{Ni}_{3.8}$, where $x=0.0,0.1,0.3,0.5$, and 0.7 , were investigated by SEM/EDX, XRD, and electrochemical measurements. The partial substitution of $\mathrm{La}$ by $\mathrm{Mg}$ refined the grain structure while the total substitution changed it from equiaxed to columnar. Three phases were detected: a major phase $(M)$, a grey phase $(G)$, and a dark phase $(D)$. The compositions analyzed by EDX suggested that the $M$ phase was close to a $\mathrm{LaNi}_{5}$ phase. With the increase of the $\mathrm{Mg}$ content, the analyses revealed a $G$ phase with composition close to a $\mathrm{RMg}_{2} \mathrm{Ni}_{9}(\mathrm{R}=\mathrm{La}, \mathrm{Pr})$ and a $D$ phase close to a $\mathrm{MgNi}_{2}$ phase. The XRD analysis and Rietveld refinement corroborated the EDX results. The corrosion resistance of the alloys was evaluated in $6.0 \mathrm{~mol} \cdot \mathrm{L}^{-1} \mathrm{KOH}$ solution, and the results showed that the substitution of La by $\mathrm{Mg}$ was beneficial for this alloy property. Nevertheless, $\mathrm{Mg}$ addition was deleterious to the discharge capacity of the electrodes.
\end{abstract}

\section{Introduction}

Over the past years, extensive research has been concentrated on the study of hydrogen storage alloys as a negative electrode of nickel-metal hydride (Ni/MH) secondary battery, as shown in recent reviews on the subject [1-5]. Commercial alloy systems for $\mathrm{Ni} / \mathrm{MH}$ batteries are rare earth-based $\mathrm{AB}_{5}$-type alloys, Ti- and $\mathrm{Zr}$-based $\mathrm{AB}_{2}$-type alloys, and, recently, $\mathrm{A}_{2} \mathrm{~B}_{7}$ and $\mathrm{AB}_{3}$-type $\mathrm{RE}-\mathrm{Mg}$-Ni-based superlattice alloys. Although representing the first generation of negative electrodes, the rare earth-based $\mathrm{AB}_{5}$-type alloys (with discharge capacity limited to $320 \mathrm{mAh} / \mathrm{g}$ ) are very popular in use on commercial $\mathrm{Ni} / \mathrm{MH}$ batteries [1]. Nickel substitution in La-Ni-type electrodes of $\mathrm{AB}_{5}$ system multicomponent metal hydride alloys has been widely reported, and the purpose of alloy modification is to improve the electrode performance. Aluminum, manganese, and/or cobalt are always present in $\mathrm{Ni} / \mathrm{MH}$ electrodes. Lanthanum is frequently substituted for cerium, neodymium, and/or praseodymium. Magnesium has also been included in this type of hydrogen storage alloys as an element that can increase the number of hydrogen atoms stored per metal atom [6]. $\mathrm{Mg}$ additions vary from impurity levels to considerable atomic concentrations aiming to reduce costs (by reducing the amount of Co) and improving cyclic stability or durability of the Ni/MH batteries [7-11].

Reported microstructural investigations and chemical analyses for as-cast hydrogen storage alloys with $\mathrm{Mg}$ addition are very scarce. This paper addresses this aspect and reports the results of a study with partial and total substitution of $\mathrm{La}$ by $\mathrm{Mg}$, on hydrogen storage $\mathrm{La}_{0.7-x} \mathrm{Mg}_{x} \mathrm{Pr}_{0.3} \mathrm{Al}_{0.3} \mathrm{Mn}_{0.4} \mathrm{Co}_{0.5} \mathrm{Ni}_{3.8}$ ascast alloys $(x=0.0,0.1,0.3,0.5$ and 0.7$)$. A thorough investigation of the microstructures of these alloys and the phases present has been carried out using SEM/EDX and XRD. Moreover, it is well known that the Ni/MH batteries work in a strong oxidizing medium composed of high-concentration alkaline electrolyte. Therefore, among the desired properties of negative electrodes alloys, high corrosion resistance is essential for long cycle lifetime [6-13]. In the present study, the corrosion resistance of the $\mathrm{La}-\mathrm{Mg}-\mathrm{Pr}-\mathrm{Al}-\mathrm{Mn}-\mathrm{Co}-\mathrm{Ni}$ alloys in $6.0 \mathrm{~mol} \cdot \mathrm{L}^{-1} \cdot \mathrm{KOH}$ solution was also investigated.

\section{Experimental Procedures}

The alloys investigated in this study were commercially prepared in $5 \mathrm{~kg}$ batches melted in induction heating vacuum equipment and cast in a cooled mold. The chemical 
TABLE 1: Composition of the as-cast $\mathrm{La}_{0.7-x} \mathrm{Mg}_{x} \mathrm{Pr}_{0.3} \mathrm{Al}_{0.3} \mathrm{Mn}_{0.4} \mathrm{Co}_{0.5} \mathrm{Ni}_{3.8}$ alloys.

\begin{tabular}{lcccccrrr}
\hline Nominal composition & $x$ & \multicolumn{5}{c}{ Specified composition (at.\%) } \\
& & $\mathrm{La}$ & $\mathrm{Pr}$ & $\mathrm{Mg}$ & $\mathrm{Al}$ & $\mathrm{Mn}$ & $\mathrm{Co}$ & $\mathrm{Ni}$ \\
\hline $\mathrm{La}_{0.7} \mathrm{Pr}_{0.3} \mathrm{Al}_{0.3} \mathrm{Mn}_{0.4} \mathrm{Co}_{0.5} \mathrm{Ni}_{3.8}$ & 0.0 & 11.67 & 5.00 & - & 5.00 & 6.67 & 8.33 \\
$\mathrm{La}_{0.6} \mathrm{Mg}_{0.1} \mathrm{Pr}_{0.3} \mathrm{Al}_{0.3} \mathrm{Mn}_{0.4} \mathrm{Co}_{0.5} \mathrm{Ni}_{3.8}$ & 0.1 & 10.00 & 5.00 & 1.67 & 5.00 & 6.67 & 8.33 & 63.33 \\
$\mathrm{La}_{0.4} \mathrm{Mg}_{0.3} \mathrm{Pr}_{0.3} \mathrm{Al}_{0.3} \mathrm{Mn}_{0.4} \mathrm{Co}_{0.5} \mathrm{Ni}_{3.8}$ & 0.3 & 6.67 & 5.00 & 5.00 & 5.00 & 6.67 & 8.33 & 63.33 \\
$\mathrm{La}_{0.2} \mathrm{Mg}_{0.5} \mathrm{Pr}_{0.3} \mathrm{Al}_{0.3} \mathrm{Mn}_{0.4} \mathrm{Co}_{0.5} \mathrm{Ni}_{3.8}$ & 0.5 & 3.34 & 5.00 & 8.33 & 5.00 & 6.67 & 8.33 & 63.33 \\
$\mathrm{Mg}_{0.7} \mathrm{Pr}_{0.3} \mathrm{Al}_{0.3} \mathrm{Mn}_{0.4} \mathrm{Co}_{0.5} \mathrm{Ni}_{3.8}$ & 0.7 & - & 5.00 & 11.67 & 5.00 & 6.67 & 8.33 & 63.33 \\
\hline
\end{tabular}
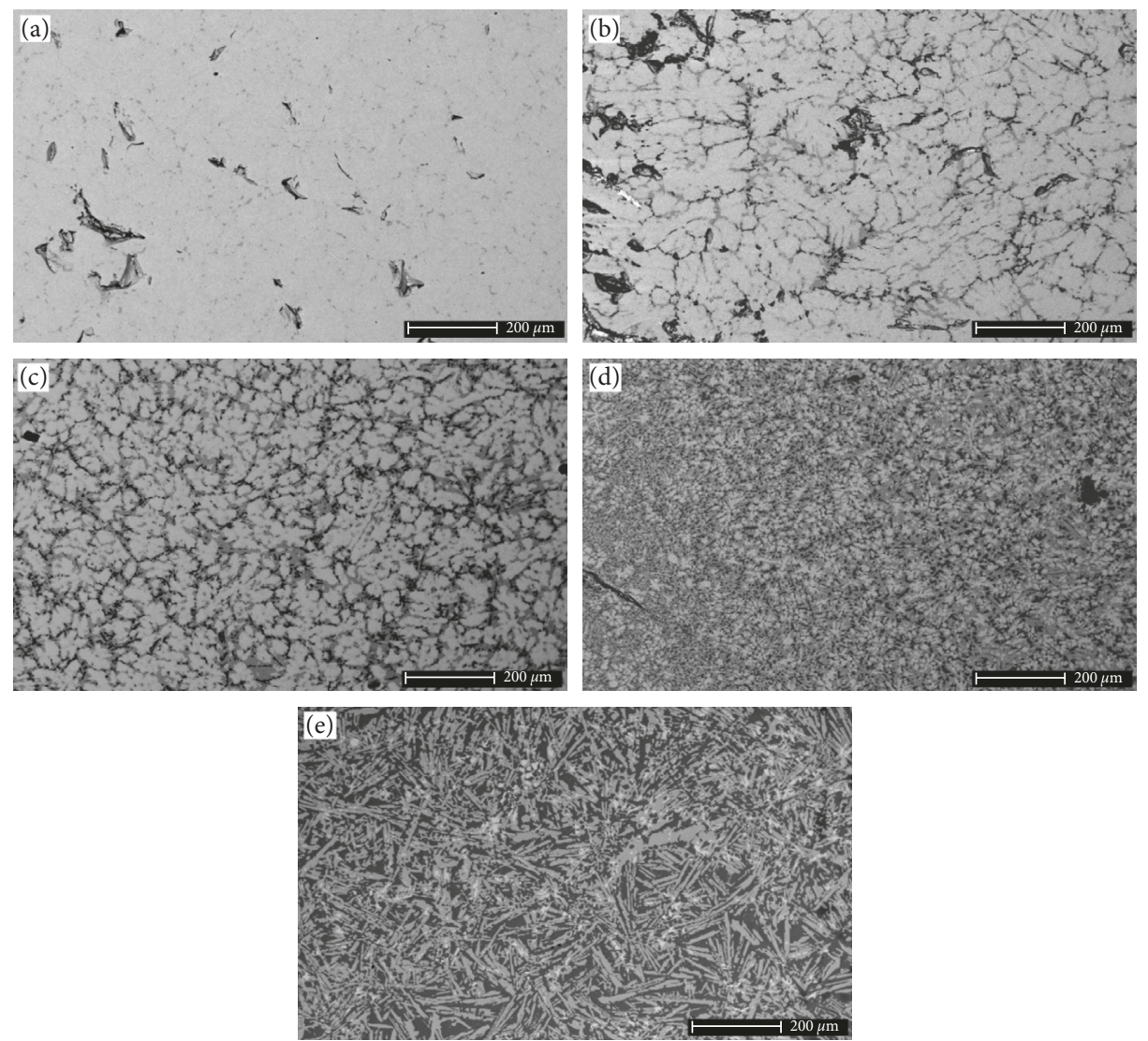

FIGURE 1: SEM micrographs showing a general view of the alloys investigated: (a) $\mathrm{La}_{0.7} \mathrm{Pr}_{0.3} \mathrm{Al}_{0.3} \mathrm{Mn}_{0.4} \mathrm{Co}_{0.5} \mathrm{Ni}_{3.8}$; (b) $\mathrm{La}_{0.6} \mathrm{Mg}_{0.1} \mathrm{Pr}_{0.3} \mathrm{Al}_{0.3} \mathrm{Mn}_{0.4} \mathrm{Co}_{0.5} \mathrm{Ni}_{3.8} ;$ (c) $\mathrm{La}_{0.4} \mathrm{Mg}_{0.3} \mathrm{Pr}_{0.3} \mathrm{Al}_{0.3} \mathrm{Mn}_{0.4} \mathrm{Co}_{0.5} \mathrm{Ni}_{3.8} ;$ (d) $\mathrm{La}_{0.2} \mathrm{Mg}_{0.5} \mathrm{Pr}_{0.3} \mathrm{Al}_{0.3} \mathrm{Mn}_{0.4} \mathrm{Co}_{0.5} \mathrm{Ni}_{3.8} ;(\mathrm{e}) \mathrm{Mg}_{0.7} \mathrm{Pr}_{0.3} \mathrm{Al}_{0.3} \mathrm{Mn}_{0.4} \mathrm{Co}_{0.5} \mathrm{Ni}_{3.8}$.

analyses of the as-cast alloys are given in Table 1. For comparison convenience, a conversion to the substitution composition (atomic \%) is also provided.

Agreement has been found between the composition specified values and that determined by analyses in the alloys. As per the supplier's analysis, the alloys contained sulfur, oxygen, carbon, and nitrogen as impurities ( $\leq 100 \mathrm{ppm})$. Specimens for microstructure investigations were prepared using standard metallographic methods. The microstructures of the samples were examined using a scanning electron microscopy (SEM) with energy dispersive X-ray (EDX) analysis facility (Philips XL30). Average data were obtained from various independent measurements from each phase. The crystal structure of the alloys was identified by X-ray diffraction (XRD) with a $\mathrm{Cu} \mathrm{K}_{\alpha}$ radiation (Rigaku DMAX-2000). The phase abundance, lattice parameters, and cell volume of the alloy phases were obtained from Rietveld refinement method using GSAS (General Structure Analysis System) program.

The corrosion studies of the alloys was evaluated by electrochemical methods, specifically electrochemical impedance spectroscopy (EIS) and potentiodynamic polarization curves (anodic and cathodic, separately). Electrochemical measurements have been used in previous papers [14, 15]. A three-electrode cell was employed in this investigation with a Pt counter electrode and a mercurous oxide $\left(\mathrm{Hg} / \mathrm{HgO} / 6.0 \mathrm{~mol} \cdot \mathrm{L}^{-1} \cdot \mathrm{KOH}\right.$ solution $)$ as a standard reference electrode. The working electrode was produced using cold epoxy resin mounting with a contact wire for electric connection. The surface for exposure to the electrolyte was polished prior testing. The corrosion behavior was investigated with a Gamry frequency response analyzer (EIS 300) linked to a potentiostat (PCI4/300). The corrosion tests were performed in a $6.0 \mathrm{~mol} \cdot \mathrm{L}^{-1} \cdot \mathrm{KOH}$ solution at room 

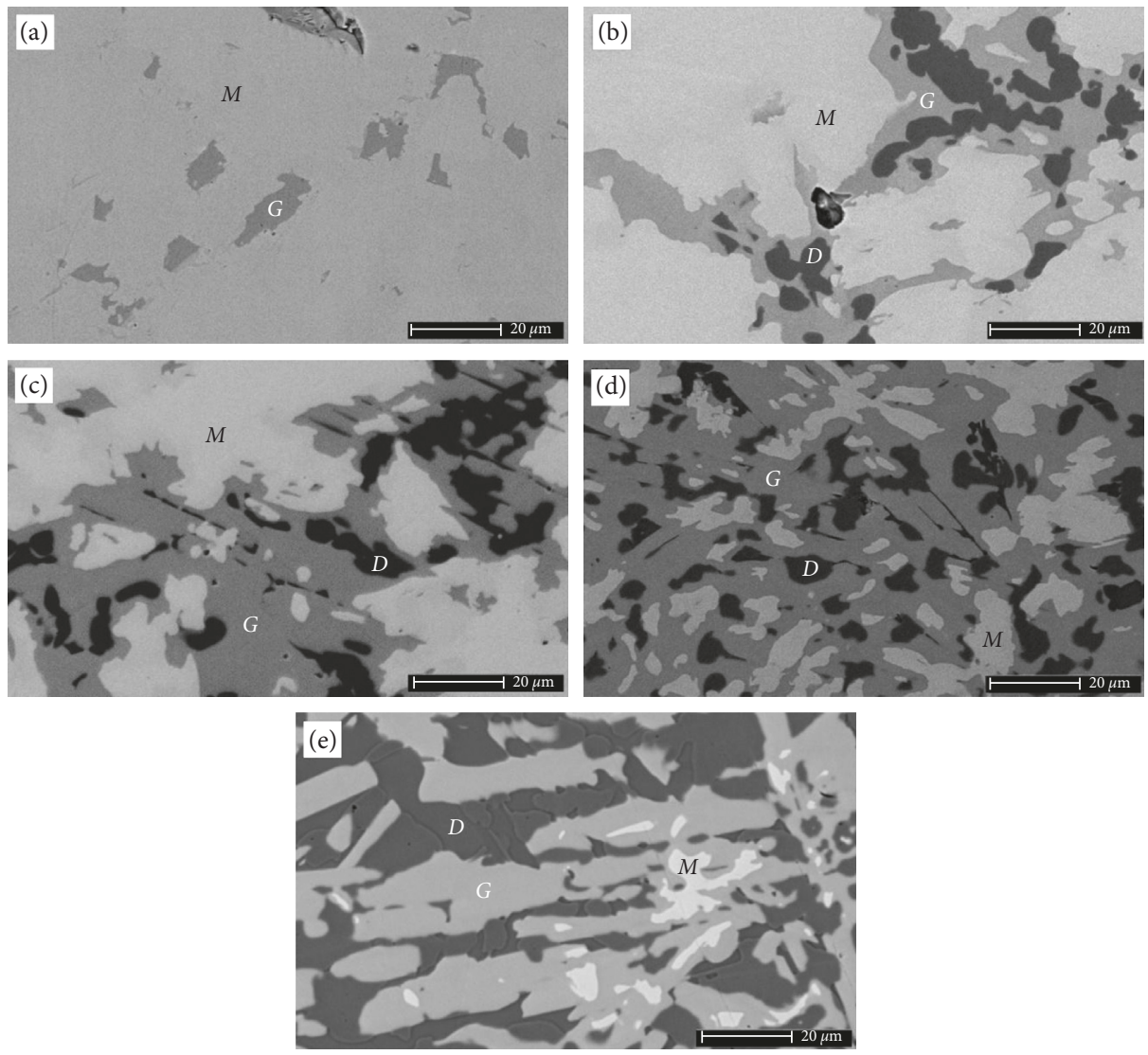

Figure 2: SEM micrographs showing the $M, G$, and $D$ phases of the alloys investigated: (a) $\operatorname{La}_{0.7} \mathrm{Pr}_{0.3} \mathrm{Al}_{0.3} \mathrm{Mn}_{0.4} \mathrm{Co}_{0.5} \mathrm{Ni}_{3.8}$; (b) $\mathrm{La}_{0.6} \mathrm{Mg}_{0.1} \mathrm{Pr}_{0.3} \mathrm{Al}_{0.3} \mathrm{Mn}_{0.4} \mathrm{Co}_{0.5} \mathrm{Ni}_{3.8} ;$ (c) $\mathrm{La}_{0.4} \mathrm{Mg}_{0.3} \mathrm{Pr}_{0.3} \mathrm{Al}_{0.3} \mathrm{Mn}_{0.4} \mathrm{Co}_{0.5} \mathrm{Ni}_{3.8} ;$ (d) $\mathrm{La}_{0.2} \mathrm{Mg}_{0.5} \mathrm{Pr}_{0.3} \mathrm{Al}_{0.3} \mathrm{Mn}_{0.4} \mathrm{Co}_{0.5} \mathrm{Ni}_{3.8} ;(\mathrm{e}) \mathrm{Mg}_{0.7} \mathrm{Pr}_{0.3} \mathrm{Al}_{0.3} \mathrm{Mn}_{0.4} \mathrm{Co}_{0.5} \mathrm{Ni}_{3.8}$.

temperature $(20 \pm 2)^{\circ} \mathrm{C}$. All the reagents employed for the test solution were per analytical (p.a.) grade.

The specimens were immersed in the test solution, and the open circuit potential (OCP) was determined as a function of time. EIS tests were performed employing perturbation voltage amplitude of $\pm 10 \mathrm{mV}$, relatively to the OCP, from $10 \mathrm{kHz}$ to $10 \mathrm{mHz}$, with an acquisition rate of 10 points/decade. Soon after the EIS tests, the OCP was measured to test the stability of the potential. Potentiodynamic polarization curves were obtained employing a scan rate of $30 \mathrm{mV} / \mathrm{s}$. Polarization curves with slower scan rates were unsuccessful due to the highly passive character of the alloys in the electrolyte employed (resulting only in scattered data). Four specimens of each commercial alloy were examined in this investigation.

Discharge capacity test electrodes were produced by pressing a mixture of $100 \mathrm{mg}$ of the commercial alloy (powdered by manual crushing to a 270 mesh sieve) and teflonized carbon (Vulcan XC-72R with $33 \mathrm{wt} . \%$ polytetrafluoroethylene) in a weight ratio of $1: 1$ on both sides of a nickel mesh (10 $\mathrm{mm}$ diameter). The charge/discharge cycling tests were carried out at $25^{\circ} \mathrm{C}$ employing a commercial battery analyzer (Arbin BT-4). Discharge capacity assessments were performed in a trielectrode cell consisting of the prepared working electrode, a coiled $\mathrm{Pt}$ wire $(0.5 \mathrm{~mm}$ in diameter and $300 \mathrm{~mm}$ long) counter electrode, and a $\mathrm{Hg} / \mathrm{HgO} / 6.0 \mathrm{~mol} \cdot \mathrm{L}^{-1} \cdot \mathrm{KOH}$ solution reference electrode in a $6.0 \mathrm{~mol} \cdot \mathrm{L}^{-1} \cdot \mathrm{KOH}$ electrolyte solution. The working electrode was charged at $100 \mathrm{~mA} / \mathrm{g}$ for $5 \mathrm{~h}$ and subsequently discharged at $50 \mathrm{~mA} / \mathrm{g}$ to the cutoff potential of $-0.6 \mathrm{~V}$ versus the $\mathrm{Hg} / \mathrm{HgO}$ reference electrode.

\section{Results and Discussion}

3.1. SEM and EDX Characterization. Backscattered electron micrographs showing a general view and details of the ascast alloys are shown in Figures 1 and 2, respectively. The $\mathrm{La}_{0.7} \mathrm{Pr}_{0.3} \mathrm{Al}_{0.3} \mathrm{Mn}_{0.4} \mathrm{Co}_{0.5} \mathrm{Ni}_{3.8}$ alloy (Figure 2(a)) is composed of a major phase $(M)$ and a grey phase $(G)$ in the grain boundaries. The other alloys are composed of three phases: $M, G$, and a dark phase $(D)$. The proportion of these three phases in the alloys changed as Mg was included and also as its content increased. Total substitution of $\mathrm{La}$ by $\mathrm{Mg}$ $(x=0.7)$ makes the $M$ phase the minor phase in the $\mathrm{Mg}_{0.7} \mathrm{Pr}_{0.3} \mathrm{Al}_{0.3} \mathrm{Mn}_{0.4} \mathrm{Co}_{0.5} \mathrm{Ni}_{3.8}$ alloy (Figure 2(e)). In this case, the $M$ phase is inside the grey phase. The morphologies of the as-cast alloys also reveal that substitution of lanthanum by magnesium results in a marked refinement in the grain structure of the alloys (Figure 1). Clearly, the magnesium-free alloy shows a coarse equiaxed grain structure, whereas the lanthanum-free alloy reveals a fine structure with columnar grain. Previous study has shown that the total substitution of lanthanum by praseodymium in the alloy changed the grain structure from equiaxed to columnar [16]. This result and the present observation 
TABLE 2: Composition determined using EDX at the centers of the $M$ phase in the as-cast $\operatorname{La}_{0.7-x} \mathrm{Mg}_{x} \mathrm{Pr}_{0.3} \mathrm{Al}_{0.3} \mathrm{Mn}_{0.4} \mathrm{Co}_{0.5} \mathrm{Ni}_{3.8}$ alloys.

\begin{tabular}{|c|c|c|c|c|c|c|c|c|}
\hline \multirow{2}{*}{$x\left(N^{*}\right)$} & \multicolumn{7}{|c|}{ Analyzed composition (at.\%) } & \multirow{2}{*}{ Ratio** } \\
\hline & $\mathrm{La}$ & $\operatorname{Pr}$ & $\mathrm{Mg}$ & $\mathrm{Al}$ & $\mathrm{Mn}$ & Co & $\mathrm{Ni}$ & \\
\hline $0.0(5)$ & $12.0 \pm 0.2$ & $4.7 \pm 0.4$ & - & $5.5 \pm 0.5$ & $5.8 \pm 1.4$ & $8.6 \pm 0.2$ & $63.4 \pm 1.3$ & 5.0 \\
\hline $0.1(2)$ & $11.0 \pm 0.5$ & $5.3 \pm 0.1$ & - & $3.6 \pm 1.1$ & $3.1 \pm 1.1$ & $7.7 \pm 0.2$ & $69.4 \pm 2.3$ & 5.1 \\
\hline $0.3(11)$ & $8.5 \pm 0.1$ & $7.0 \pm 0.4$ & - & $4.2 \pm 0.6$ & $3.1 \pm 0.9$ & $8.2 \pm 0.4$ & $68.0 \pm 1.5$ & 5.4 \\
\hline $0.5(11)$ & $5.9 \pm 0.2$ & $9.7 \pm 0.3$ & - & $3.6 \pm 0.4$ & $3.1 \pm 0.5$ & $8.0 \pm 0.4$ & $70.0 \pm 0.7$ & 5.4 \\
\hline $0.7(5)$ & - & $14.0 \pm 0.2$ & - & $3.4 \pm 0.4$ & $2.8 \pm 0.3$ & $7.6 \pm 0.3$ & $72.0 \pm 0.8$ & 6.1 \\
\hline
\end{tabular}

${ }^{*}$ Number of independent measurements from the $M$ phase. ${ }^{* *}(\mathrm{La}, \mathrm{Pr}) /(\mathrm{Al}, \mathrm{Mn}, \mathrm{Co}, \mathrm{Ni})$.

TABle 3: Composition determined using EDX at the centers of the $G$ phase in the as-cast $\operatorname{La}_{0.7-x} \mathrm{Mg}_{x} \mathrm{Pr}_{0.3} \mathrm{Al}_{0.3} \mathrm{Mn}_{0.4} \mathrm{Co}_{0.5} \mathrm{Ni}_{3.8}$ alloys.

\begin{tabular}{|c|c|c|c|c|c|c|c|c|}
\hline \multirow{2}{*}{$x\left(N^{*}\right)$} & \multicolumn{7}{|c|}{ Analyzed composition (at.\%) } & \multirow{2}{*}{ Ratio** } \\
\hline & $\mathrm{La}$ & $\operatorname{Pr}$ & $\mathrm{Mg}$ & $\mathrm{Al}$ & $\mathrm{Mn}$ & Co & $\mathrm{Ni}$ & \\
\hline $0.0(8)$ & $8.1 \pm 0.4$ & $2.3 \pm 0.4$ & - & $4.0 \pm 0.3$ & $21.8 \pm 1.4$ & $8.5 \pm 0.8$ & $55.3 \pm 1.3$ & - \\
\hline $0.1(4)$ & $6.4 \pm 0.3$ & $2.9 \pm 0.2$ & $10.9 \pm 0.4$ & $2.9 \pm 0.2$ & $10.3 \pm 0.4$ & $7.9 \pm 0.3$ & $58.7 \pm 0.5$ & $1: 2.3: 7.5$ \\
\hline $0.3(7)$ & $5.0 \pm 0.3$ & $4.3 \pm 0.2$ & $12.0 \pm 0.6$ & $3.7 \pm 0.1$ & $6.5 \pm 0.5$ & $7.4 \pm 0.2$ & $61.0 \pm 0.3$ & $1: 2.0: 8.0$ \\
\hline $0.5(2)$ & $3.5 \pm 0.2$ & $5.9 \pm 0.3$ & $12.4 \pm 0.4$ & $2.8 \pm 0.1$ & $4.8 \pm 0.5$ & $6.8 \pm 0.6$ & $63.8 \pm 0.2$ & $1: 1.8: 7.8$ \\
\hline $0.7(6)$ & - & $9.1 \pm 0.3$ & $12.5 \pm 0.5$ & $1.7 \pm 0.2$ & $3.8 \pm 0.3$ & $5.8 \pm 0.5$ & $67.0 \pm 0.7$ & $1: 1.8: 8.2$ \\
\hline
\end{tabular}

${ }^{*}$ Number of independent measurements from the $G$ phase. ${ }^{* *}(\mathrm{La}, \mathrm{Pr}) /(\mathrm{Mg}) /(\mathrm{Al}, \mathrm{Mn}, \mathrm{Co}, \mathrm{Ni})$.

TABle 4: Composition determined using EDX at the centers of the $D$ phase in the as-cast $\operatorname{La}_{0.7-x} \mathrm{Mg}_{x} \mathrm{Pr}_{0.3} \mathrm{Al}_{0.3} \mathrm{Mn}_{0.4} \mathrm{Co}_{0.5} \mathrm{Ni}_{3.8}$ alloys.

\begin{tabular}{|c|c|c|c|c|c|c|c|c|}
\hline \multirow{2}{*}{$x\left(N^{*}\right)$} & \multicolumn{7}{|c|}{ Analyzed composition (at.\%) } & \multirow{2}{*}{ Ratio** $^{*}$} \\
\hline & $\mathrm{La}$ & $\operatorname{Pr}$ & $\mathrm{Mg}$ & $\mathrm{Al}$ & $\mathrm{Mn}$ & Co & $\mathrm{Ni}$ & \\
\hline $0.1(4)$ & $<1$ & $<1$ & $<1$ & $16-17$ & $23-24$ & $7-8$ & $49-50$ & 1.4 \\
\hline $0.3(6)$ & $<1$ & $<1$ & $1-8$ & $10-17$ & $15-16$ & $15-16$ & $56-57$ & 2.8 \\
\hline $0.5(8)$ & $<1$ & $<1$ & $1-18$ & $3-11$ & $12-13$ & $15-16$ & $60-63$ & 3.1 \\
\hline $0.7(5)$ & - & $<1$ & $21-23$ & $1-2$ & $7-9$ & $5-13$ & $61-65$ & 2.0 \\
\hline
\end{tabular}

${ }^{*}$ Number of independent measurements from the $D$ phase. ${ }^{* *}(\mathrm{Pr}, \mathrm{Mg}, \mathrm{Al}, \mathrm{Mn}) /(\mathrm{Co}, \mathrm{Ni})$.

indicate that the presence of lanthanum in the alloys favors an equiaxed grain structure.

The chemical composition of the major phase in the different alloys, as determined by EDX, is presented in Table 2 . The $M$ phase in the $\mathrm{Mg}$-free alloy revealed a ( $\mathrm{La}, \mathrm{Pr}):(\mathrm{Al}$, $\mathrm{Mn}, \mathrm{Co}, \mathrm{Ni}$ ) atomic ratio of 5.0 , indicating it to be a $1: 5$ phase (similar to $\mathrm{LaNi}_{5}$ ). This result would be in agreement with the $\mathrm{LaNi}_{5}$ matrix phase observed in previous studies [17-20]. The subsequent alloys $(x>0.0)$ showed that this $(\mathrm{La}, \mathrm{Pr})$ : (Al, $\mathrm{Mn}, \mathrm{Co}, \mathrm{Ni}$ ) atomic ratio increases due to the substitution of $\mathrm{La}$ by $\mathrm{Mg}$. Despite the increase of the praseodymium content, the total rare earth content in the $M$ phase decreased from 16.7 at.\% to 14.0 at.\% with the total substitution of La by $\mathrm{Mg}$. Conversely, the nickel content in the $M$ phase of these alloys increased from 63.4 at.\% to 72.0 at.\% with this substitution. The amount of aluminum and manganese in this phase decreased somewhat with increasing magnesium content in the alloys. The cobalt content showed an average close to 8 at.\%.

The chemical composition of the grey phase observed in all alloys, also determined using EDX, is shown in Table 3. As in the previous case, in all alloys the La content showed a decrease, whereas the Pr content increases in this phase. The measured value of the rare earth (9.1 10.4 at.\%) was more than half of that found in the $M$ phase (14.0 16.7 at.\%). The magnesium content in this grey phase was as high as 12.5 at.\%, which indicates the preferential concentration of this element in this phase. Similar to that observed in the matrix phase, the amount of $\mathrm{Al}$ and $\mathrm{Mn}$ in the grey phase diminished with the substitution of $\mathrm{La}$ by $\mathrm{Mg}$. The aluminum content in the $G$ phase (1.7 4.0 at.\%) was somewhat lower than that found in the $M$ phase (3.4 5.5 at.\%). It was also detected a manganese concentration peak in the $\mathrm{Mg}$ free alloy ( 22 at.\%), which indicated the presence of a possible phase rich in $\mathrm{Mn}$, in a very reduced amount, as observed in the correspondent micrograph (Figure 2(a)). The presence of this phase can be attributed to the as-cast state of the alloys. On the other hand, in the alloys with $x>0.0$, the grey phase revealed a ( $\mathrm{La}, \mathrm{Pr}): \mathrm{Mg}$ : (Al,Mn,Co, $\mathrm{Ni}$ ) atomic ratio close to $1: 2: 9$. This ratio would indicate the presence of phase similar to the $\mathrm{RMg}_{2} \mathrm{Ni}_{9}$ type, in agreement with the system $\mathrm{AB}_{2} \mathrm{C}_{9}[21,22]$. The average cobalt content ( $\sim 7$ at.\%) was close to that in the $M$ phase ( $~ 8$ at.\%).

The chemical composition of the dark phase in the different alloys is presented in Table 4. This phase has not been found in the Mg-free alloy. Apparently, magnesium influences the microstructure and also the phases that can be found in the alloys. In this phase, the rare earth content was 


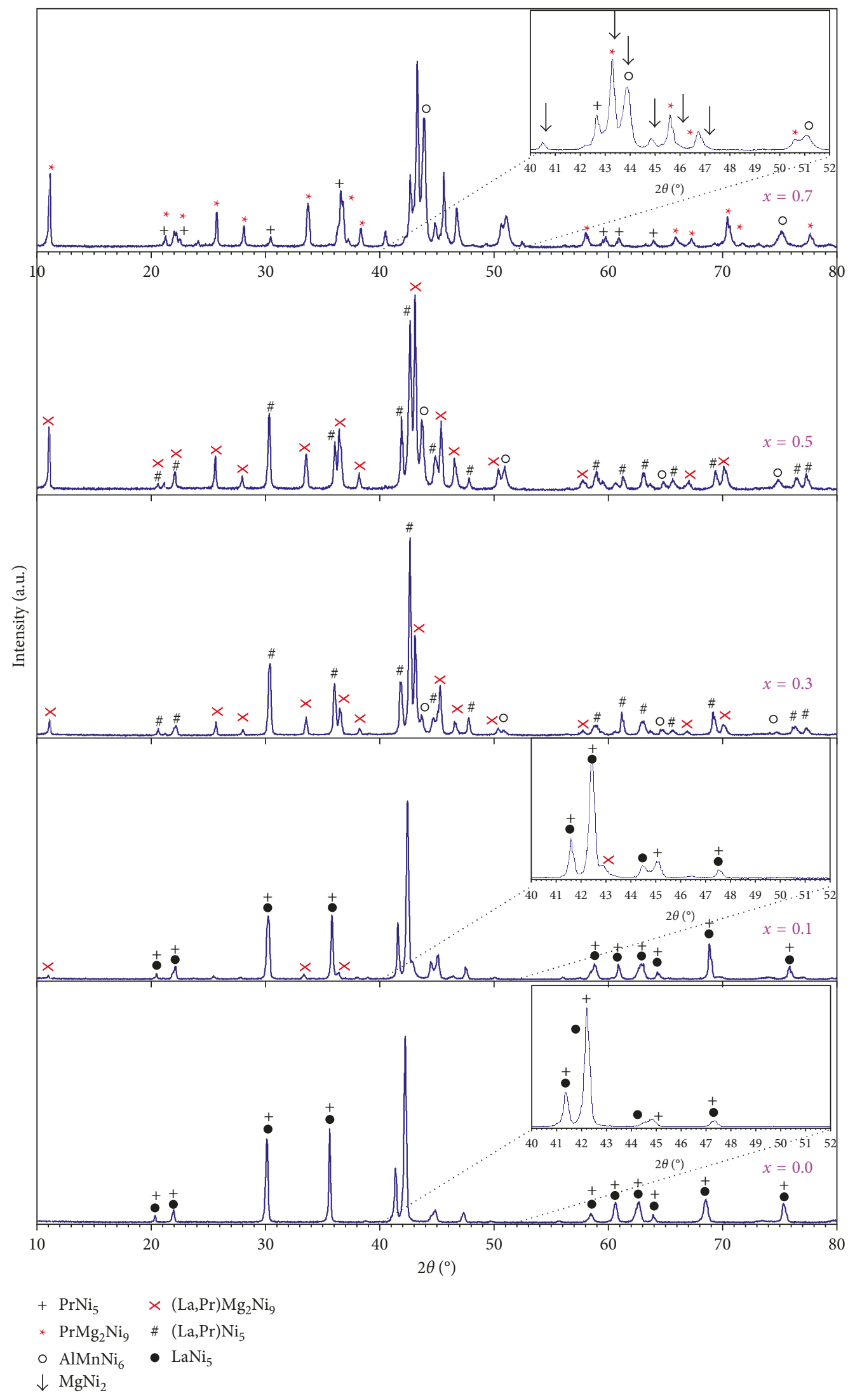

FIgURE 3: XRD profiles of the $\mathrm{La}_{0.7-x} \mathrm{Mg}_{x} \mathrm{Pr}_{0.3} \mathrm{Al}_{0.3} \mathrm{Mn}_{0.4} \mathrm{Co}_{0.5} \mathrm{Ni}_{3.8}(x=0.0-0.7)$ alloys. 
TABLE 5: The characteristics of alloy phases in the $\mathrm{La}_{0.7-x} \mathrm{Mg}_{x} \mathrm{Pr}_{0.3} \mathrm{Al}_{0.3} \mathrm{Mn}_{0.4} \mathrm{Co}_{0.5} \mathrm{Ni}_{3.8}(x=0.0-0.7)$ alloys.

\begin{tabular}{|c|c|c|c|c|c|c|c|}
\hline \multirow[t]{2}{*}{ Samples } & \multirow[t]{2}{*}{ Phases } & \multirow[t]{2}{*}{ Space group } & \multirow[t]{2}{*}{ Parameters of fit ${ }^{\mathrm{a}}$} & \multirow[t]{2}{*}{ Phase abundance (wt.\%) } & \multicolumn{2}{|c|}{$\begin{array}{c}\text { Lattice } \\
\text { parameter }(\AA ́)\end{array}$} & \multirow[t]{2}{*}{ Cell volume $\left(\AA^{3}\right)$} \\
\hline & & & & & $a$ & $c$ & \\
\hline \multirow[t]{2}{*}{$x=0.0$} & $\mathrm{LaNi}_{5}$ & $\mathrm{P} 6 / \mathrm{mmm}$ & $R_{\mathrm{p}}=0.2660$ & 74.2 & 5.047 & 4.063 & $89.6 \pm 0.5$ \\
\hline & $\mathrm{PrNi}_{5}$ & $\mathrm{P} 6 / \mathrm{mmm}$ & $R_{\mathrm{wp}}=0.4664, \chi^{2}=2.757$ & 25.8 & 5.034 & 4.034 & $88.5 \pm 0.5$ \\
\hline \multirow[t]{3}{*}{$x=0.1$} & $\mathrm{LaNi}_{5}$ & $\mathrm{P} 6 / \mathrm{mmm}$ & $R_{\mathrm{p}}=0.2416$ & 43.0 & 5.017 & 4.062 & $88.5 \pm 0.5$ \\
\hline & $\mathrm{PrNi}_{5}$ & $\mathrm{P} 6 / \mathrm{mmm}$ & $R_{\mathrm{wp}}=0.4440, \chi^{2}=2.467$ & 45.5 & 5.020 & 4.019 & $87.7 \pm 0.5$ \\
\hline & $(\mathrm{La}, \mathrm{Pr}) \mathrm{Mg}_{2} \mathrm{Ni}_{9}$ & $\mathrm{R}-3 \mathrm{~m}$ & & 11.5 & 4.950 & 24.299 & $516 \pm 1$ \\
\hline \multirow[t]{3}{*}{$x=0.3$} & $(\mathrm{La}, \mathrm{Pr}) \mathrm{Ni}_{5}$ & $\mathrm{P} 6 / \mathrm{mmm}$ & $R_{\mathrm{p}}=0.2416$ & 60.7 & 4.996 & 4.051 & $87.6 \pm 0.5$ \\
\hline & $(\mathrm{La}, \mathrm{Pr}) \mathrm{Mg}_{2} \mathrm{Ni}_{9}$ & $\mathrm{R}-3 \mathrm{~m}$ & $R_{\mathrm{wp}}=0.4440, \chi^{2}=2.467$ & 29.3 & 4.936 & 24.104 & $509 \pm 1$ \\
\hline & $\mathrm{AlMnNi}_{6}$ & $\mathrm{Pm} 3 \mathrm{~m}$ & & 10.0 & 3.603 & 3.603 & $46.8 \pm 0.5$ \\
\hline \multirow[t]{3}{*}{$x=0.5$} & $(\mathrm{La}, \mathrm{Pr}) \mathrm{Ni}_{5}$ & $\mathrm{P} 6 / \mathrm{mmm}$ & $R_{\mathrm{p}}=0.2469$ & 32.6 & 4.981 & 4.041 & $86.8 \pm 0.5$ \\
\hline & $(\mathrm{La}, \mathrm{Pr}) \mathrm{Mg}_{2} \mathrm{Ni}_{9}$ & $\mathrm{R}-3 \mathrm{~m}$ & $R_{\mathrm{wp}}=0.6088, \chi^{2}=2.148$ & 42.6 & 4.932 & 23.993 & $505 \pm 1$ \\
\hline & $\mathrm{AlMnNi}_{6}$ & $\mathrm{Pm} 3 \mathrm{~m}$ & & 24.8 & 3.590 & 3.590 & $46.3 \pm 0.5$ \\
\hline \multirow[t]{4}{*}{$x=0.7$} & $\mathrm{PrNi}_{5}$ & $\mathrm{P} 6 / \mathrm{mmm}$ & $R_{\mathrm{p}}=0.2056$ & 5.8 & 4.943 & 4.028 & $85.2 \pm 0.5$ \\
\hline & $\mathrm{PrMg}_{2} \mathrm{Ni}_{9}$ & $\mathrm{R}-3 \mathrm{~m}$ & $R_{\mathrm{wp}}=0.3734, \chi^{2}=2.249$ & 46.4 & 4.918 & 23.906 & $501 \pm 1$ \\
\hline & $\mathrm{AlMnNi}_{6}$ & $\mathrm{Pm} 3 \mathrm{~m}$ & & 33.5 & 3.583 & 3.583 & $46.0 \pm 0.5$ \\
\hline & $\mathrm{MgNi}_{2}$ & $\mathrm{P}_{3} / \mathrm{mmc}$ & & 14.3 & 4.834 & 15.824 & $320 \pm 1$ \\
\hline
\end{tabular}

${ }^{\mathrm{a}} R_{\mathrm{p}}=$ pattern factor; $R_{\mathrm{wp}}=$ weighted pattern factor; $\chi^{2}=$ goodness of fit.

close or below the EDX detection limit, indicating the preferential concentration of these elements in the other detected phases. For $x=0.1$, the dark phase was richer in manganese and aluminum in contrast to the other constituents (except $\mathrm{Ni}$ ). Only in the La-free alloy $(x=0.7)$ was observed a magnesium concentration peak. The approximated atomic relation between $\mathrm{Mg}$ and $\mathrm{Ni}$ in this alloy suggests the presence of similar phase to the $\mathrm{MgNi}_{2}$ phase. This observation would be in agreement upon observations in the synthesis of ternary $\mathrm{RMg}_{2} \mathrm{Ni}_{9}$ alloys by sintering of powders of $\mathrm{MgNi}_{2}$ and $\mathrm{RNi}_{5}(\mathrm{R}=\mathrm{La}, \mathrm{Ce}, \mathrm{Pr}, \mathrm{Nd}, \mathrm{Sm}$, and Gd) [22]. Except for $x=0.7$, the values measured showed a preferential presence of aluminum in the $D$ phase in comparison with the concentrations found in the $M$ and $G$ phases. In the case of manganese, after the peak of concentration in $x=0.1$, it was observed a decrease in the other compositions. For the cobalt content, some variations with higher values of $x=0.3$ and 0.5 were observed. It must be kept in mind that the characterization of the alloys was carried out in the as-cast state, and deviation in the results can be attributed to the alloys' heterogeneous condition. This is consistent with previous studies $[18,23]$, where it was shown that, in a $\mathrm{La}_{0.7} \mathrm{Mg}_{0.3} \mathrm{Al}_{0.2} \mathrm{Mn}_{0.1} \mathrm{Co}_{0.75} \mathrm{Ni}_{2.45}$ alloy, annealing at high temperature was essential to achieve a homogeneous composition. EDX determinations indicate phase compositions close to $\mathrm{LaNi}_{5}$ in the phase matrix, $\mathrm{RMg}_{2} \mathrm{Ni}_{9}(\mathrm{R}=\mathrm{La}, \mathrm{Pr})$ in the grey phase, and $\mathrm{MgNi}_{2}$ in the dark phase.

3.2. XRD Characterization. The XRD profiles of the $\mathrm{La}_{0.7-x} \mathrm{Mg}_{x} \mathrm{Pr}_{0.3} \mathrm{Al}_{0.3} \mathrm{Mn}_{0.4} \mathrm{Co}_{0.5} \mathrm{Ni}_{3.8}(x=0.0,0.1,0.3,0.5,0.7)$ as-cast alloys are shown in Figure 3 . It can be observed that the diffraction peaks were shifted to higher angles due to the La substitution (atomic radius $2.74 \AA$ ) by $\mathrm{Mg}$ (atomic radius $1.72 \AA$ ), also noting the constant presence of $\operatorname{Pr}$ (atomic radius $2.67 \AA$ ) in all compositions. The identification of phases by XRD was based on the results obtained by SEM/EDX. The identified phases, the lattice parameters, unit cell volumes, and Rietveld phase abundance are listed in Table 5 and are also shown in Figures 4 and 5. The substitution led to a decrease in the lattice parameters and unit cells of the phases present in the alloys. There have been identified phases with similar crystalline symmetry and spatial group as reference phases $\mathrm{LaNi}_{5}, \mathrm{PrNi}_{5}, \mathrm{LaMg}_{2} \mathrm{Ni}_{9}$, $\mathrm{PrMg}_{2} \mathrm{Ni}_{9}, \mathrm{AlMnNi}_{6}$, and $\mathrm{MgNi}_{2}$. However, for the $a$ and $c$ parameters, there have been observed variations when compared to these reference phases. There have been attributed to possible substitutions in the crystalline lattice in the sites of $\mathrm{La}(\mathrm{La}, \mathrm{Pr})$ and of $\mathrm{Ni}(\mathrm{Al}, \mathrm{Mn}, \mathrm{Co}, \mathrm{Ni})$ as a consequence of the as-cast state of the alloys. Both, this condition and the increased substitution of $\mathrm{La}$ by $\mathrm{Mg}$, influenced the phase's relative abundance, as shown in Figure 5. Also shown in this figure are the correspondence with the matrix phase $(M)$, grey phase $(G)$, and dark phase $(D)$, all determined by SEM/EDX analyses for the Mg alloys.

The phase abundance of the phase similar to $\mathrm{LaNi}_{5}$ for $x=0.0$ and 0.1 diminished from $74.2 \%$ to $43.0 \%$, whereas for the phase similar to $\mathrm{PrNi}_{5}$ increased from $25.8 \%$ to $45.5 \%$. It was also detected for $x=0.1$ a phase similar to (La, $\mathrm{Pr}) \mathrm{Mg}_{2} \mathrm{Ni}_{9}$ (11.5\%). The abundance of this phase showed a steady increase with the amount of $\mathrm{Mg}$ in the alloy $(x=0.1$ to 0.5$)$ and the detection of a $\mathrm{PrMg}_{2} \mathrm{Ni}_{9}$-type phase on the total substitution of $\mathrm{La}$ by $\mathrm{Mg}\left(\mathrm{Mg}_{0.7} \mathrm{Pr}_{0.3} \mathrm{Al}_{0.3} \mathrm{Mn}_{0.4} \mathrm{Co}_{0.5} \mathrm{Ni}_{3.8}\right)$.

(La,Pr) $\mathrm{Ni}_{5}$ shifted from major abundance $(60.7 \%)$ for $x=0.3$ to minor abundance $(5.8 \%)$ for $x=0.7$. It has also been identified from $x=0.3$ a phase similar to the $\mathrm{AlMnNi}_{6}$ phase in increasing abundance that reached $33.5 \%$ for $x=0.7$. In this condition, that is, total substitution of La by $\mathrm{Mg}$, it has been detected a phase similar to the $\mathrm{MgNi}_{2}$ phase (14.3\%). The identification of phases present in the alloys by 

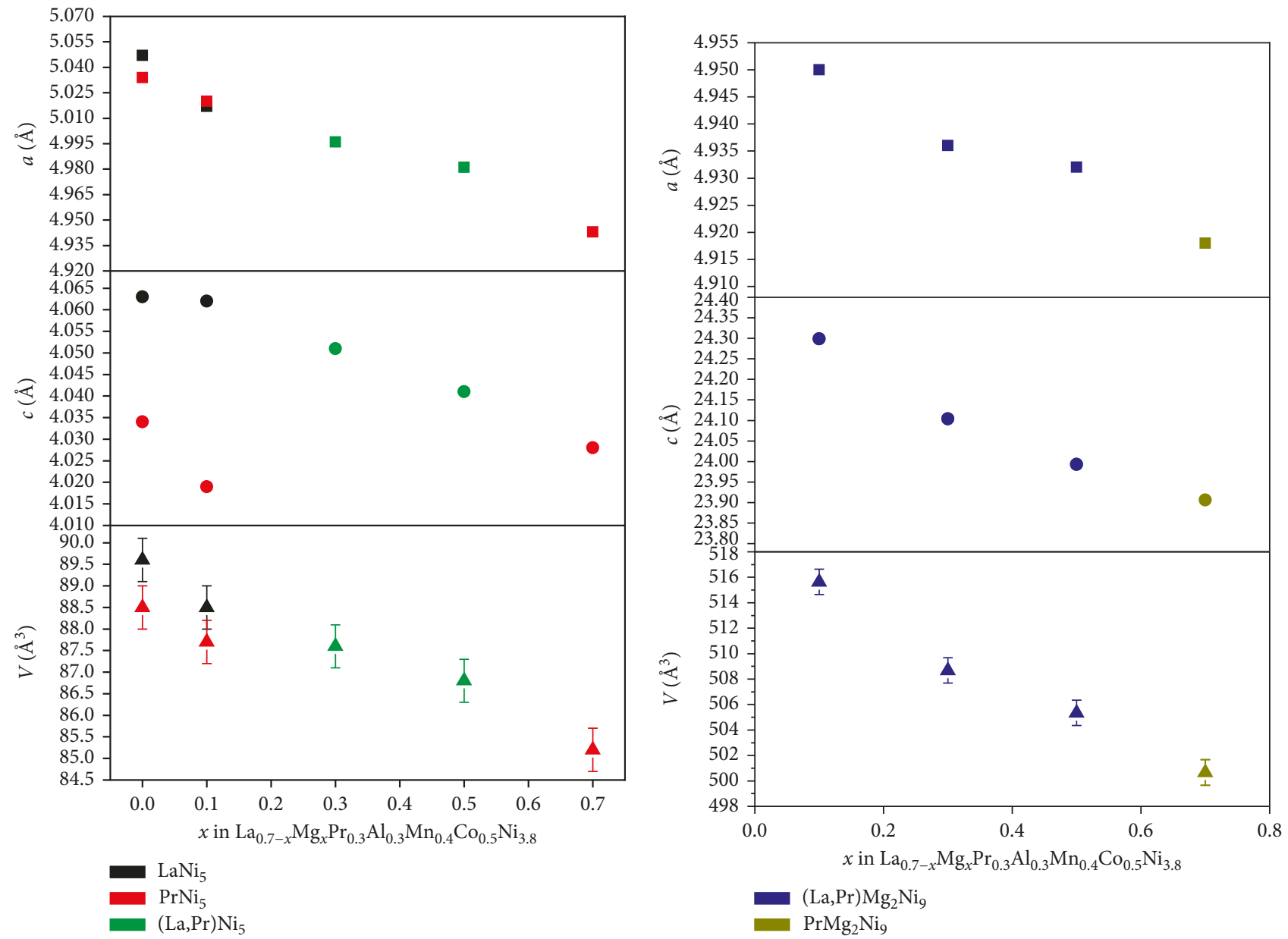

(a)

(b)

FIgURE 4: The lattice parameters and cell volumes of the $\mathrm{La}_{0.7-x} \mathrm{Mg}_{x} \mathrm{Pr}_{0.3} \mathrm{Al}_{0.3} \mathrm{Mn}_{0.4} \mathrm{Co}_{0.5} \mathrm{Ni}_{3.8}$ ( $\left.x=0.0-0.7\right)$ alloys: (a) $\mathrm{LaNi}_{5}, \mathrm{PrNi}_{5}$, and ( $\mathrm{La}$, $\mathrm{Pr}) \mathrm{Ni}_{5}$ phases; (b) (La,Pr) $\mathrm{Mg}_{2} \mathrm{Ni}_{9}$ and $\mathrm{PrMg}_{2} \mathrm{Ni}_{9}$ phases.

XRD and SEM/EDX led to the following correspondences: $M$ to $\mathrm{LaNi}_{5}$ and $\mathrm{PrNi}_{5}$-type phases, $G$ to $\mathrm{LaMg}_{2} \mathrm{Ni}_{9}$ and PrMg ${ }_{2} \mathrm{Ni}_{9}$-type phases, and $D$ to $\mathrm{MgNi}_{2}$ and $\mathrm{AlMnNi}_{6}$-type phases.

\subsection{Electrochemical Characterization}

3.3.1. Corrosion. Figure 6 shows the anodic potentiodynamic polarization curves for the various tested alloys. At the corrosion potential, most alloys presented very low current densities (i), in the order of $10^{-5}$ to $10^{-6} \mathrm{~A} / \mathrm{cm}^{2}$, typical of passive materials, but the lowest $i$ value was related to the alloy with the highest $\mathrm{Mg}$-content $(x=0.7)$. For the alloy without $\mathrm{Mg}(x=0)$, the current density largely increased with overpotential showing that the passive film on this alloy had the lowest resistance. The passive films on the alloys with 0.6 and 0.4 at.\% La content showed intermediate resistances, between that without $\mathrm{Mg}$ and that without La. These results show that electrochemical behavior of the alloys was highly dependent on their microstructures. The substitution of $\mathrm{La}$ by $\mathrm{Mg}$ that led to refinement in the grain structure also had a beneficial effect on their corrosion resistance.
The polarization curves show that from the corrosion potential up to $0.7 \mathrm{~V}$ the effect of the alloy composition and consequently its microstructure on the electrochemical behavior is clearly seen with the lowest current densities associated with the alloys with lower La contents, that is, increasing $\mathrm{Mg}$ concentration. At potentials of nearly $0.7 \mathrm{~V}$, all alloys showed a current density increase, and from $0.8 \mathrm{~V}$ upwards the electrochemical behavior of the alloys with $\mathrm{Mg}$ contents of $0.0,0.1,0.3$, and 0.5 at. $\%$ was similar. On the other hand, for the alloy with total substitution of La by $\mathrm{Mg}$, the current density values were lower than the other alloys in the whole potential range.

The Nyquist diagrams for the various alloys studied are shown in Figure 7. The EIS results showed higher impedances associated with the samples with the higher $\mathrm{Mg}$ contents $(x=0.5$ and $x=0.7)$, indicating a passive behavior for these alloys. The lowest impedances were associated with the alloy without $\mathrm{Mg}$ and supported the polarization results that indicated that this alloy presented the lowest corrosion resistance.

The Bode phase angle diagrams in Figure 8 show two time constants for all studied alloys with lower phase angles 


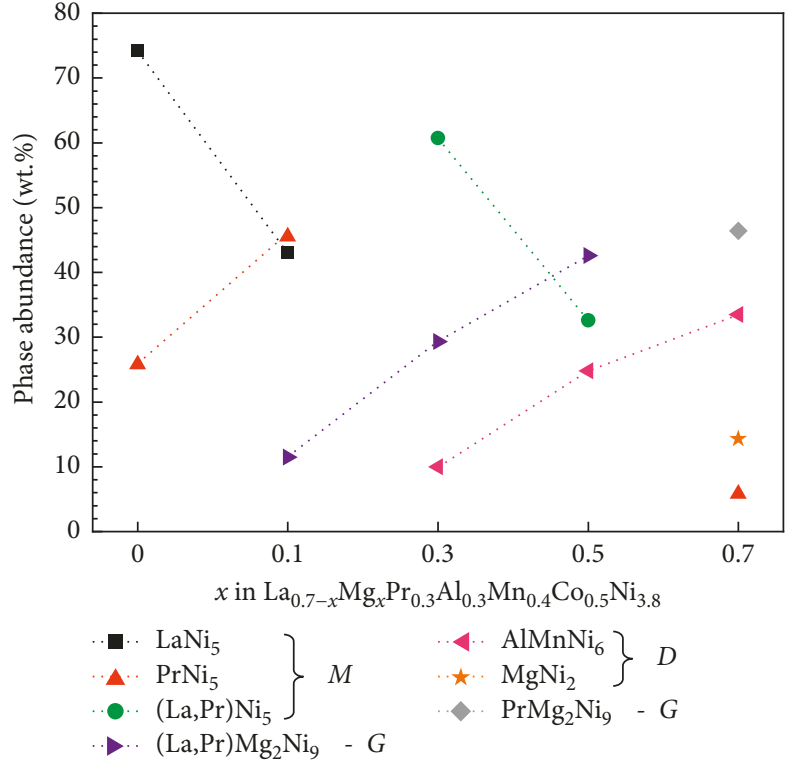

FIgURE 5: The phase abundance of the $\mathrm{La}_{0.7-x} \mathrm{Mg}_{x} \mathrm{Pr}_{0.3} \mathrm{Al}_{0.3} \mathrm{Mn}_{0.4} \mathrm{Co}_{0.5} \mathrm{Ni}_{3.8}$ $(x=0.0-0.7)$ alloys.

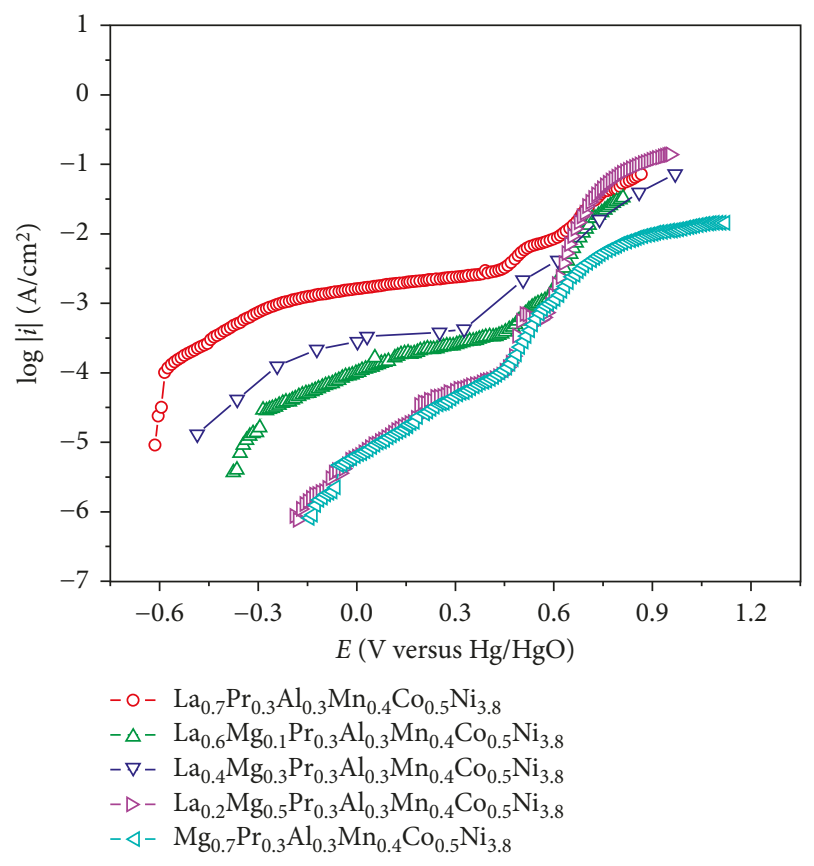

Figure 6: Anodic polarization curves of the $\mathrm{La}_{0.7-x} \mathrm{Mg}_{x} \mathrm{Pr}_{0.3} \mathrm{Al}_{0.3} \mathrm{Mn}_{0.4} \mathrm{Co}_{0.5} \mathrm{Ni}_{3.8}(x=0,0.1,0.3,0.5$, and 0.7$)$ alloys in $6.0 \mathrm{~mol} \cdot \mathrm{L}^{-1} \cdot \mathrm{KOH}$ solution.

related to the alloys with low $\mathrm{Mg}$ contents $(0.0,0.1$, and 0.3 at.\%). For the alloys with 0.5 or 0.7 at. $\% \mathrm{Mg}$ (without $\mathrm{La}$ ), the time constant at high frequencies is seen at approximately $1 \mathrm{kHz}$, whereas for the other alloys, this time constant occurs at nearly $0.1 \mathrm{kHz}$. For all alloys, the second time constant is seen at approximately the same frequency, $0.1 \mathrm{~Hz}$. The high frequency time constant is related to the surface oxide/hydroxide film, whereas the one at lower frequencies

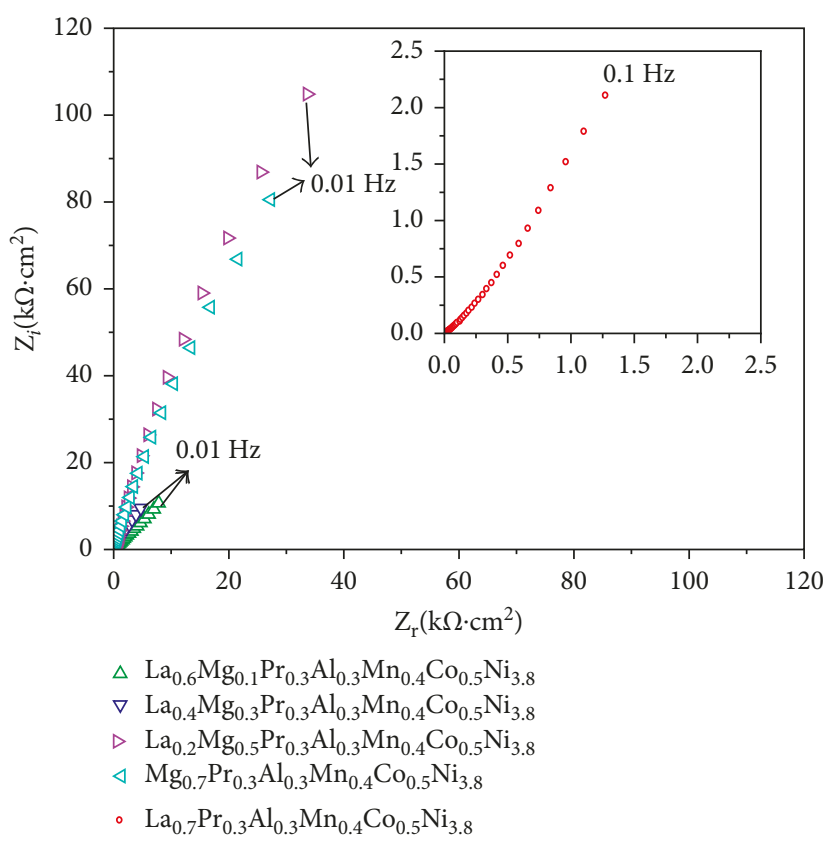

FIGURE 7: Nyquist diagrams of the $\mathrm{La}_{0.7-} \mathrm{Mg}_{x} \mathrm{Pr}_{0.3} \mathrm{Al}_{0.3} \mathrm{Mn}_{0.4} \mathrm{Co}_{0.5} \mathrm{Ni}_{3.8}$ $(x=0,0.1,0.3,0.5$, and 0.7$)$ alloys tested in $6.0 \mathrm{~mol} \cdot \mathrm{L}^{-1} \cdot \mathrm{KOH}$ solution.

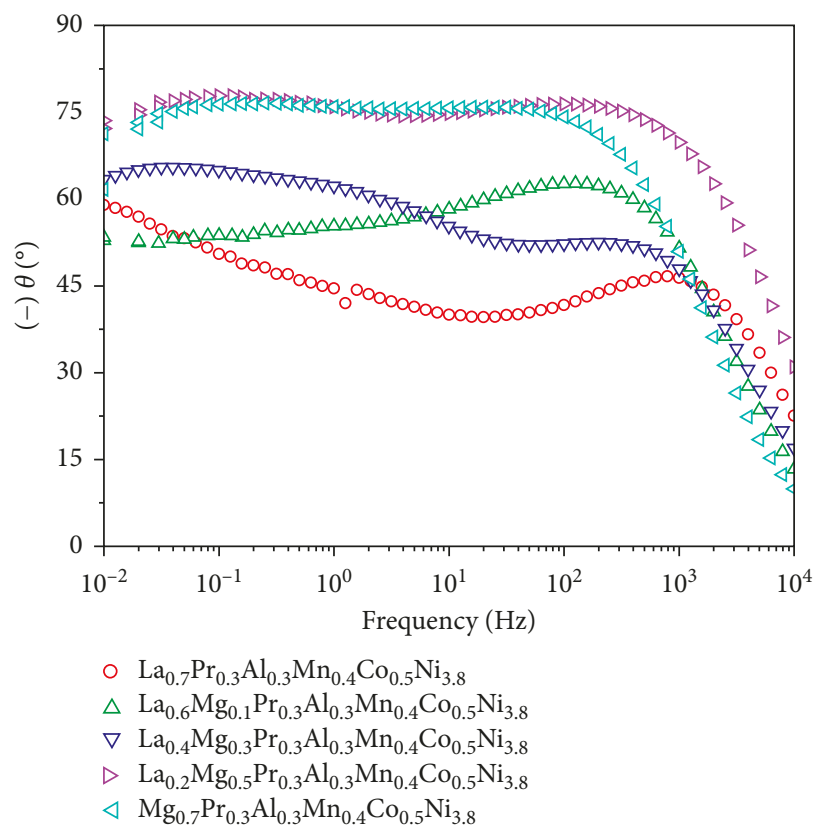

Figure 8: Bode phase angle diagrams of the $\mathrm{La}_{0.7-x} \mathrm{Mg}_{x} \mathrm{Pr}_{0.3} \mathrm{Al}_{0.3} \mathrm{Mn}_{0.4} \mathrm{Co}_{0.5} \mathrm{Ni}_{3.8} \quad(x=0,0.1,0.3,0.5$ and 0.7$)$ alloys tested in $6.0 \mathrm{~mol} \cdot \mathrm{L}^{-1} \cdot \mathrm{KOH}$ solution.

is associated with charge transfer processes. These results indicate that more protective surface films are formed on the alloys with the high $\mathrm{Mg}$ contents. This is most likely related to the refined grain microstructure associated with these alloys and shows that the substitution of La by $\mathrm{Mg}$ increases the alloy corrosion resistance mainly due to the formation of a more protective oxide film on their surface comparatively 


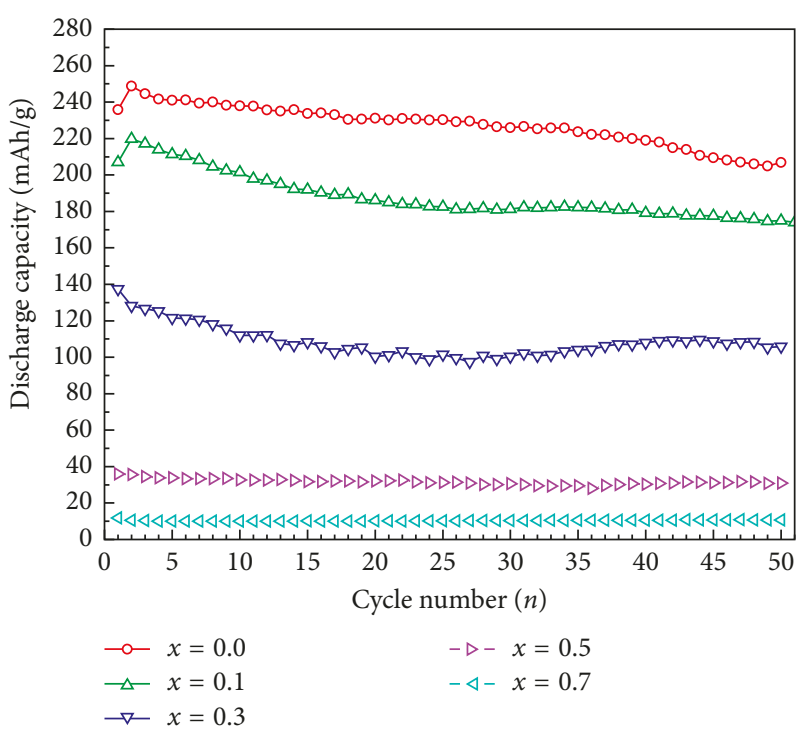

Figure 9: Discharge capacity of the $\mathrm{La}_{0.7-x} \mathrm{Mg}_{x} \mathrm{Pr}_{0.3} \mathrm{Al}_{0.3} \mathrm{Mn}_{0.4} \mathrm{Co}_{0.5} \mathrm{Ni}_{3.8}$ alloys versus cycle number.

to that formed on the alloys with larger La contents. Passive surface films such as $\mathrm{La}(\mathrm{OH})_{3}$ and $\mathrm{Mg}(\mathrm{OH})_{2}$ have been reported in literature for La-Mg-Ni ternary alloy systems $[24,25]$. Due to the very low reduction potentials associated with $\mathrm{Mg}$ and rare earth elements, such as $\mathrm{La}$ and $\mathrm{Pr}$, in alkaline environments, these types of passive films are fairly stable [26].

3.3.2. Discharge Capacity. Figure 9 shows the discharge capacity characteristics of the alloy electrodes with cycling. The range of measured discharge capacity values, limited to $250 \mathrm{mAh} / \mathrm{g}$, could be attributed to superficial oxide formation during the preparation of the electrodes in the air. It can be seen that the electrodes can be easily activated within 2 cycles. Higher discharge capacity values were obtained for the $\mathrm{Mg}$-free alloy with a maximum of $250 \mathrm{mAh} / \mathrm{g}$ and for $x=0.1$ (maximum of $220 \mathrm{mAh} / \mathrm{g}$ ). A significant decrease was observed for $x=0.3$ (maximum $\sim 140 \mathrm{mAh} / \mathrm{g}$ ), and a dramatic reduction in this property with higher amount of $\mathrm{Mg}$ was observed. Clearly, increasing the magnesium content on the alloys decreased the discharge capacity of the negative electrodes. From the structural viewpoint, the increasing amount of $\mathrm{Mg}$ decreased the presence of the phase similar to the $\mathrm{LaNi}_{5}$-type phase in the alloys, and the consequent increase of the abundance of the others observed phases (phases similar to the (La, $\mathrm{Pr}) \mathrm{Mg}_{2} \mathrm{Ni}_{9}$ and $\mathrm{MgNi}_{2}$ phases). Notwithstanding the limitation of the discharge capacity showed experimentally by the $\mathrm{LaNi}_{5}$ phase (hexagonal, type $\left.\mathrm{CaCu}_{5}\right)[5,27]$, the performance of this phase still overcame the ( $\mathrm{La}, \mathrm{Pr}) \mathrm{Mg}_{2} \mathrm{Ni}_{9}$ and $\mathrm{MgNi}_{2}$ phases. The (La, $\left.\mathrm{Pr}\right) \mathrm{Mg}_{2} \mathrm{Ni}_{9}$ phases follow the structural model formed by the relation between the subunities $\left(\mathrm{MgNi}_{2}\right) /\left(\mathrm{LaNi}_{5}\right)$ equal to 2 . The subunity $\mathrm{MgNi}_{2}$ present (Laves phases, hexagonal type $\mathrm{MgNi}_{2}$ ) shows some slow performance for hydrogen storage very similar to that individually presented by the $\mathrm{MgNi}_{2}$ alloy (H/M 0.33\% in mass) [21]. Conversely, the hydride

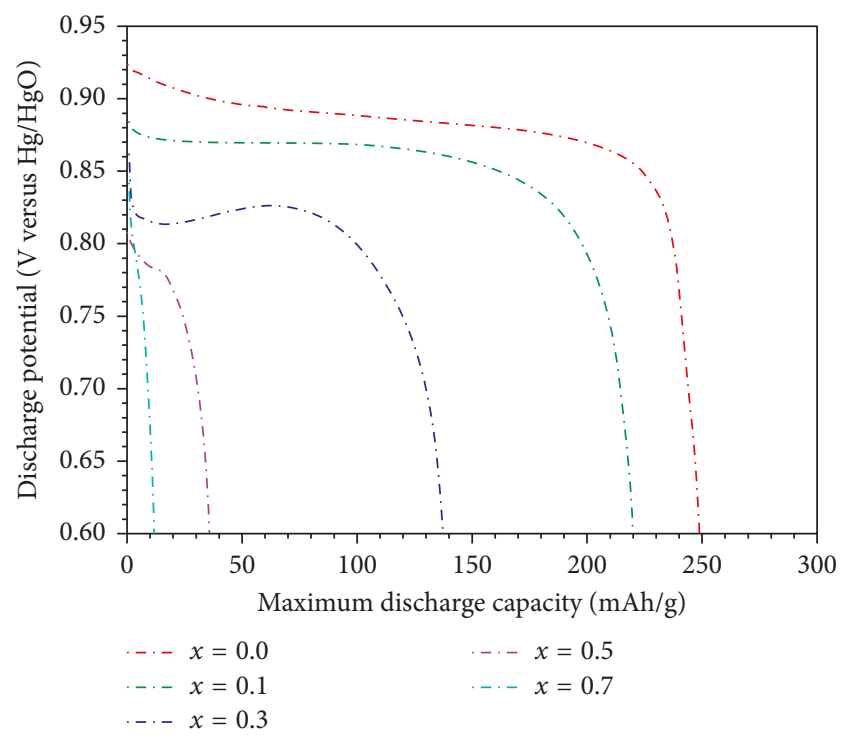

FIgUre 10: The discharge potential curves of the $\mathrm{La}_{0.7-x} \mathrm{Mg}_{x} \mathrm{Pr}_{0.3} \mathrm{Al}_{0.3} \mathrm{Mn}_{0.4} \mathrm{Co}_{0.5} \mathrm{Ni}_{3.8}$ ( $\left.x=0.0-0.7\right)$ alloys.

corresponding to the $\mathrm{LaNi}_{5}$ phase shows a hydrogen storage capacity H/M of $1.4 \%$ in mass [28]. Thus, comparatively, the higher abundance of the phase similar to the $\mathrm{LaNi}_{5}$ phase demonstrated to be beneficial to a higher discharge capacity of the electrodes. Furthermore, the refining of the alloys' microstructure that followed the increasing substitution of La by Mg showed unfavorable to the discharge capacity. Counteracting this effect, the refining proved to be beneficial to the corrosion resistance, as indicated by the experimental results. Thus, magnesium addition proved to be favorable to the corrosion properties, but high amounts have shown to be deleterious to the discharge capacity of the alloy electrodes tested. The overall discharge capacities of the present as-cast $\mathrm{La}_{0.7-x} \mathrm{Mg}_{x} \mathrm{Pr}_{0.3} \mathrm{Al}_{0.3} \mathrm{Mn}_{0.4} \mathrm{Co}_{0.5} \mathrm{Ni}_{3.8}$ alloys were somewhat superior to those obtained using mechanical alloying with a composition of $\mathrm{La}_{1-x} \mathrm{Mg}_{x} \mathrm{Al}_{0.4} \mathrm{Mn}_{0.3} \mathrm{Co}_{0.3} \mathrm{Ni}_{3.8}$ ( $\left.x=0-0.2\right)$ [7]. On the other hand, better discharge capacities were obtained with La-rich mischmetal (MI) electrodes of $\mathrm{MI}_{1-x} \mathrm{Mg}_{x} \mathrm{Al}_{0.10} \mathrm{Mn}_{0.10} \mathrm{Co}_{0.55} \mathrm{Ni}_{3.0} \quad(x=0.05-0.30)$ alloys [8]. These discrepancies can be attributed to the alloy preparation method, to testing conditions, and to the slight differences in the alloys compositions.

Figure 10 shows the discharge potential curves of the ascast $\mathrm{La}_{0.7-x} \mathrm{Mg}_{x} \mathrm{Pr}_{0.3} \mathrm{Al}_{0.3} \mathrm{Mn}_{0.4} \mathrm{Co}_{0.5} \mathrm{Ni}_{3.8}(x=0.0-0.7)$ alloys. It is well known that the principle of operation of a Ni/MH battery is based on the ability of certain metals, alloys, or intermetallics to absorb hydrogen in a reversible way. The hydride formation/decomposition process occurs via electrochemical charge transfer reaction $[5,29]$. It can be seen in Figure 10 that for the first three conditions of substitution of La by $\mathrm{Mg}(x=0.0, x=0.1$, and $x=0.3)$ it is possible to identify two regions that are commonly present in the curves of discharge potentials. The relatively flat part is called potential plateau and corresponds to the discharge process controlled by charge transfer. On the other hand, the final part of the curve represents the striking decrease of the potential due to 
the depletion of hydrogen atoms from the electrode surface. Additionally, the discharge potential also decreases with the increase of the internal resistance of the alloy. The internal resistance of alloy generally includes contact resistance, charge transfer resistance, and diffusion resistance [30]. The $\mathrm{La}_{0.7} \mathrm{Pr}_{0.3} \mathrm{Al}_{0.3} \mathrm{Mn}_{0.4} \mathrm{Co}_{0.5} \mathrm{Ni}_{3.8}(x=0.0)$ electrode alloy presented the longest potential plateau, indicating more effective charge transfer process and lower internal resistance compared to the other studied alloys. Again, the substitution of La by Mg in the alloys studied, considering the structural changes that resulted, proved to be deleterious to the discharge capacity of the electrodes.

\section{Conclusions}

From the structures and electrochemical properties of the as-cast $\mathrm{La}_{0.7-x} \mathrm{Mg}_{x} \mathrm{Pr}_{0.3} \mathrm{Al}_{0.3} \mathrm{Mn}_{0.4} \mathrm{Co}_{0.5} \mathrm{Ni}_{3.8}(x=0.0-0.7)$ alloys investigated in this study, some conclusion can be summarized:

(1) The substitution of La by Mg in the hydrogen storage alloys refined the grain microstructure. Total substitution changed the structure of the grains from equiaxed to columnar. The investigated alloys consisted of $\mathrm{LaNi}_{5^{-}}, \mathrm{PrNi}_{5^{-}}, \mathrm{LaMg}_{2} \mathrm{Ni}_{9^{-}}$, and $\mathrm{PrMg}_{2} \mathrm{Ni}_{9}{ }^{-}$ type phases, and the lattice parameters and cell volumes of the phases decreased with increasing $\mathrm{Mg}$ content.

(2) The electrochemical results showed that the $\mathrm{Mg}$ addition leads to corrosion improvement likely due to a more protective oxide film formed on the refined grain microstructure of the substrate. The results also indicated that at nonpolarized conditions all alloys showed very low current densities, indicating a passive behavior. Hence, the corrosion resistance of the studied alloys is not a limiting property for their use as negative electrodes in Ni/MH batteries.

(3) Magnesium inclusion in the alloys studied proved to be deleterious to the discharge capacity, with the maximum discharge capacity decreased with the amount of $\mathrm{Mg}$ substitution, from $250 \mathrm{mAh} / \mathrm{g}$ $(x=0.0)$ to $12 \mathrm{mAh} / \mathrm{g}(x=0.7)$, which corresponds to a fact that the abundance of a similar $\mathrm{LaNi}_{5}$ reference phase decrease with increasing Mg content.

(4) Based on the effect of substitution of Mg by La on the characteristics of the alloys and performance of the electrodes, it has been found that the $\mathrm{La}_{0.7} \mathrm{Pr}_{0.3} \mathrm{Al}_{0.3} \mathrm{Mn}_{0.4} \mathrm{Co}_{0.5} \mathrm{Ni}_{3.8}$ alloy could work as a base alloy for nonstoichiometry in the system $\mathrm{AB}_{5}$ together with the addition of small amounts of $\mathrm{Mg}$ aiming the improvement of $\mathrm{Ni} / \mathrm{MH}$ battery electrodes.

\section{Conflicts of Interest}

The authors declare that they have no conflicts of interest.

\section{Acknowledgments}

The authors wish to thank FAPESP and IPEN-CNEN/SP for the financial support and infrastructure made available to carry out this investigation.

\section{References}

[1] L. Ouyang, J. Huang, H. Wang, J. Liu, and M. Zhu, "Progress of hydrogen storage alloys for $\mathrm{Ni}-\mathrm{MH}$ rechargeable power batteries in electric vehicles: a review," Materials Chemistry and Physics, vol. 200, pp. 164-178, 2017.

[2] H. Zhang, X. Zheng, X. Tian, Y. Liu, and X. Li, "New approaches for rare earth-magnesium based hydrogen storage alloys," Progress in Natural Science: Materials International, vol. 27, no. 1, pp. 50-57, 2017.

[3] K. Young and J. Nei, "The current status of hydrogen storage alloy development for electrochemical applications," Materials, vol. 6, no. 10, pp. 4574-4608, 2013.

[4] Y. Liu, H. Pan, M. Gao, and Q. Wang, "Advanced hydrogen storage alloys for $\mathrm{Ni} / \mathrm{MH}$ rechargeable batteries," Journal of Materials Chemistry, vol. 21, no. 13, pp. 4743-4755, 2011.

[5] Y. Liu, Y. Cao, L. Huang, M. Gao, and H. Pan, "Rare earth$\mathrm{Mg}$-Ni-based hydrogen storage alloys as negative electrode materials for Ni/MH batteries," Journal of Alloys and Compounds, vol. 509, no. 3, pp. 675-686, 2011.

[6] F. Feng, M. Geng, and D. O. Northwood, "Electrochemical behaviour of intermetallic-based metal hydrides used in $\mathrm{Ni} /$ Metal hydride $(\mathrm{MH})$ batteries: a review," International Journal of Hydrogen Energy, vol. 26, no. 7, pp. 725-734, 2001.

[7] D. J. Cuscueta, M. Melnichuk, H. A. Peretti, H. R. Salva, and A. A. Ghilarducci, "Magnesium influence in the electrochemical properties of La-Ni base alloy for Ni-MH batteries," International Journal of Hydrogen Energy, vol. 33, no. 13, pp. 3566-3570, 2008.

[8] Z. Zhang, S. Han, Y. Li, and T. Jing, "Electrochemical properties of $\mathrm{Ml}_{1-x} \mathrm{Mg}_{x} \mathrm{Ni}_{3.0} \mathrm{Mn}_{0.10} \mathrm{Co}_{0.55} \mathrm{Al}_{0.10}(x=0.05-0.30)$ hydrogen storage alloys," Journal of Alloys and Compounds, vol. 431, no. 1-2, pp. 208-211, 2007.

[9] R. Tang, Y. Liu, C. Zhu, J. Zhu, and G. Yu, "Effect of Mg on the hydrogen storage characteristics of $\mathrm{Ml}_{1-x} \mathrm{Mg}_{x} \mathrm{Ni}_{2.4} \mathrm{Co}_{0.6}(x=$ 0-0.6) alloys," Materials Chemistry and Physics, vol. 95, no. 1, pp. 130-134, 2006.

[10] T. Ozaki, H. B. Yang, T. Iwaki et al., "Development of Mgcontaining $\mathrm{MmNi}_{5}$-based alloys for low-cost and high-power Ni-MH battery," Journal of Alloys and Compounds, vol. 408-412, pp. 294-300, 2006.

[11] X. Zhang, Y. Chai, W. Yin, and M. Zhao, "Crystal structure and electrochemical properties of rare earth nonstoichiometric $\mathrm{AB}_{5}$-type alloy as negative electrode material in Ni-MH battery," Journal of Solid State Chemistry, vol. 177, no. 7, pp. 2373-2377, 2004.

[12] A. K. Shukla, S. Venugopalan, and B. Hariprakash, "Nickelbased rechargeable batteries," Journal of Power Sources, vol. 100, no. 1-2, pp. 125-148, 2001.

[13] K. Hong, "The development of hydrogen storage alloys and the progress of nickel hydride batteries," Journal of Alloys and Compounds, vol. 321, no. 2, pp. 307-313, 2001.

[14] E. P. Banczek, L. M. C. Zarpelon, R. N. Faria, and I. Costa, "Corrosion resistance and microstructure characterization of rare-earth-transition metal-aluminum-magnesium alloys," Journal of Alloys and Compounds, vol. 479, no. 1-2, pp. 342-347, 2009.

[15] L. M. C. Zarpelon and R. N. Faria, "Microstructure and electrochemical characteristics of LaPrMgAlMnCoNi hydrogen storage alloys for nickel-metal hydrides batteries," Materials Science Forum, vol. 802, pp. 421-426, 2014.

[16] L. M. C. Zarpelon, E. Galego, H. Takiishi, and R. N. Faria, "Microstructure and composition of rare earth-transition metal-aluminium-magnesium alloys," Materials Research, vol. 11, no. 1, pp. 17-21, 2008. 
[17] H. Pan, X. Wu, M. Gao, N. Chen, Y. Yue, and Y. Lei, "Structure and electrochemical properties of $\mathrm{La}_{0.7} \mathrm{Mg}_{0.3} \mathrm{Ni}_{2.45-x} \mathrm{Co}_{0.75} \mathrm{Mn}_{0.1} \mathrm{Al}_{0.2} \mathrm{~W}_{x}$ $(x=0-0.15)$ hydrogen storage alloys," International Journal of Hydrogen Energy, vol. 31, no. 4, pp. 517-523, 2006.

[18] H. Pan, N. Chen, M. Gao, R. Li, Y. Lei, and Q. Wang, "Effects of annealing temperature on structure and the electrochemical properties of $\mathrm{La}_{0.7} \mathrm{Mg}_{0.3} \mathrm{Ni}_{2.45} \mathrm{Co}_{0.75} \mathrm{Mn}_{0.1} \mathrm{Al}_{0.2}$ hydrogen storage alloy," Journal of Alloys and Compounds, vol. 397, no. 1-2, pp. 306-312, 2005.

[19] P. Zhang, X. Wei, Y. Liu, J. Zhu, Z. Zhang, and T. Zhao, “The microstructures and electrochemical properties of nonstoichiometric low-Co $\mathrm{AB}_{5}$ alloys containing small amounts of Mg," Journal of Alloys and Compounds, vol. 399, no. 1-2, pp. 270-275, 2005.

[20] Y. Liu, H. Pan, M. Gao, Y. Zhu, Y. Lei, and Q. Wang, "The effect of Mn substitution for $\mathrm{Ni}$ on the structural and electrochemical properties of $\mathrm{La}_{0.7} \mathrm{Mg}_{0.3} \mathrm{Ni}_{2.55-x} \mathrm{Co}_{0.45} \mathrm{Mn}_{x}$ hydrogen storage electrode alloys," International Journal of Hydrogen Energy, vol. 29, no. 3, pp. 297-305, 2004.

[21] K. Kadir, T. Sakai, and I. Uehara, "Structural investigation and hydrogen storage capacity of $\mathrm{LaMg}_{2} \mathrm{Ni}_{9}$ and $\left(\mathrm{La}_{0.65} \mathrm{Ca}_{0.35}\right)$ $\left(\mathrm{Mg}_{1.32} \mathrm{Ca}_{0.68}\right) \mathrm{Ni}_{9}$ of the $\mathrm{AB}_{2} \mathrm{C}_{9}$ type structure," Journal of Alloys and Compounds, vol. 302, no. 1-2, pp. 112-117, 2000.

[22] K. Kadir, T. Sakai, and I. Uehara, "Synthesis and structure determination of a new series of hydrogen storage alloys: $\mathrm{RMg}_{2} \mathrm{Ni}_{9}\left(\mathrm{R}=\mathrm{La}, \mathrm{Ce}, \mathrm{Pr}, \mathrm{Nd}, \mathrm{Sm}\right.$ and Gd) built from $\mathrm{MgNi}_{2}$ Laves-type layers alternating with $\mathrm{AB}_{5}$ layers," Journal of Alloys and Compounds, vol. 257, no. 1-2, pp. 115-121, 1997.

[23] Y. Liu, H. Pan, R. Li, and Y. Lei, "Effects of Al on cycling stability of a new rare-earth $\mathrm{Mg}$-based hydrogen storage alloy," Materials Science Forum, vol. 475-479, pp. 2457-2462, 2005.

[24] B. Liao, Y. Q. Lei, G. L. Lu, L. X. Chen, H. G. Pan, and Q. D. Wang, "The electrochemical properties of $\mathrm{La}_{x} \mathrm{Mg}_{3-x} \mathrm{Ni}_{9}$ $(x=1.0-2.0)$ hydrogen storage alloys," Journal of Alloys and Compounds, vol. 356-357, pp. 746-749, 2003.

[25] B. Liao, Y. Q. Lei, L. X. Chen, G. L. Lu, H. G. Pan, and Q. D. Wang, "Effect of the $\mathrm{La} / \mathrm{Mg}$ ratio on the structure and electrochemical properties of $\mathrm{La}_{x} \mathrm{Mg}_{3-x} \mathrm{Ni}_{9} \quad(x=1.6-2.2)$ hydrogen storage electrode alloys for nickel-metal hydride batteries," Journal of Power Sources, vol. 129, no. 2, pp. 358$367,2004$.

[26] A. J. Bard, R. Parsons, and J. Jordan, Standard Potentials in Aqueous Solutions,IUPAC, Marcel Dekker, New York, NY, USA, 1985.

[27] J. J. Reilly, G. D. Adzic, J. R. Johnson, T. Vogt, S. Mukerjee, and J. McBreen, "The correlation between composition and electrochemical properties of metal hydride electrodes," Journal of Alloys and Compounds, vol. 293-295, pp. 569-582, 1999.

[28] J. J. G. Willems, "Metal hydride electrodes stability of $\mathrm{LaNi}_{5}$ related compounds," Philips Journal of Research, vol. 39, no. 1, pp. 1-94, 1984.

[29] P. H. L. Notten and P. Hokkeling, "Double-phase hydride forming compounds: a new class of highly electrocatalytic materials," Journal of the Electrochemical Society, vol. 138, no. 7, pp. 1877-1885, 1991.

[30] X. Tian, W. Wei, R. Duan et al., "Preparation and electrochemical properties of $\mathrm{La}_{0.70} \mathrm{Mg}_{x} \mathrm{Ni}_{2.45} \mathrm{Co}_{0.75} \mathrm{Al}_{0.30}$ ( $x=0,0.30$, $0.33,0.36,0.39$ ) hydrogen storage alloys," Journal of Alloys and Compounds, vol. 672, pp. 104-109, 2016. 


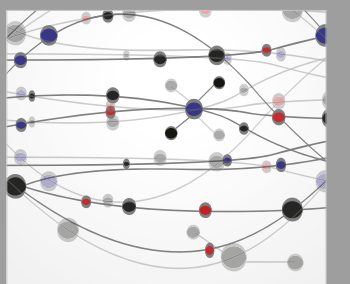

The Scientific World Journal
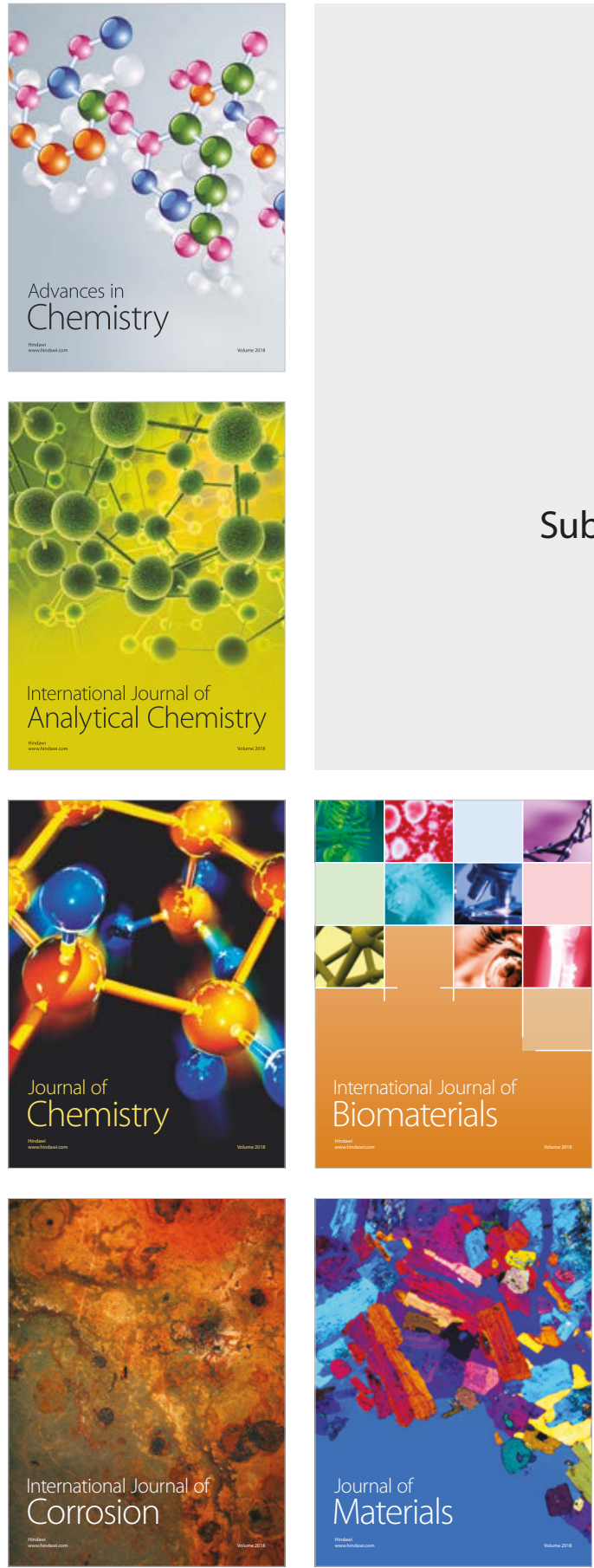

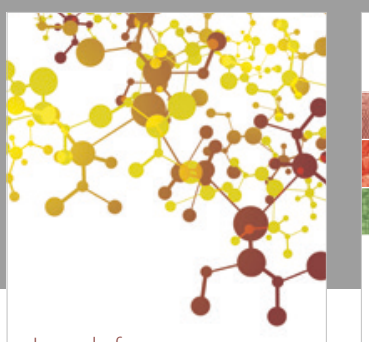

Journal of

Applied Chemistry
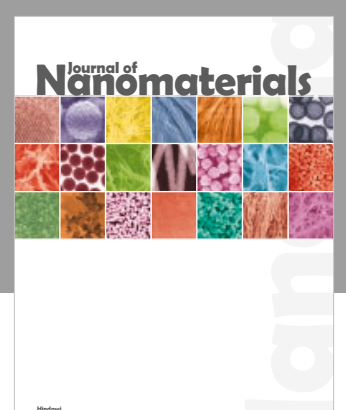

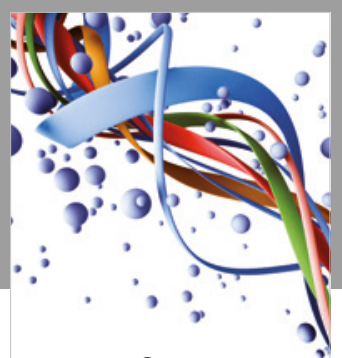

Scientifica

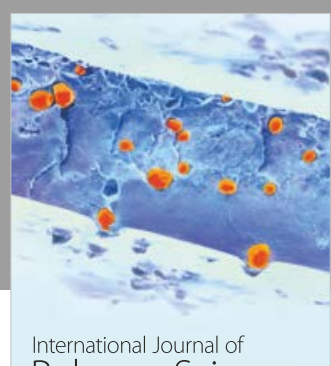

Polymer Science

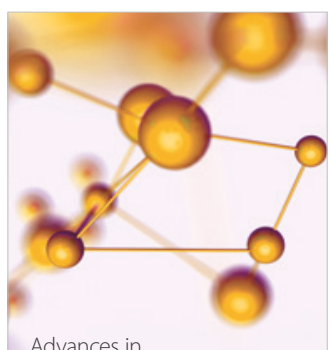

Physical Chemistry
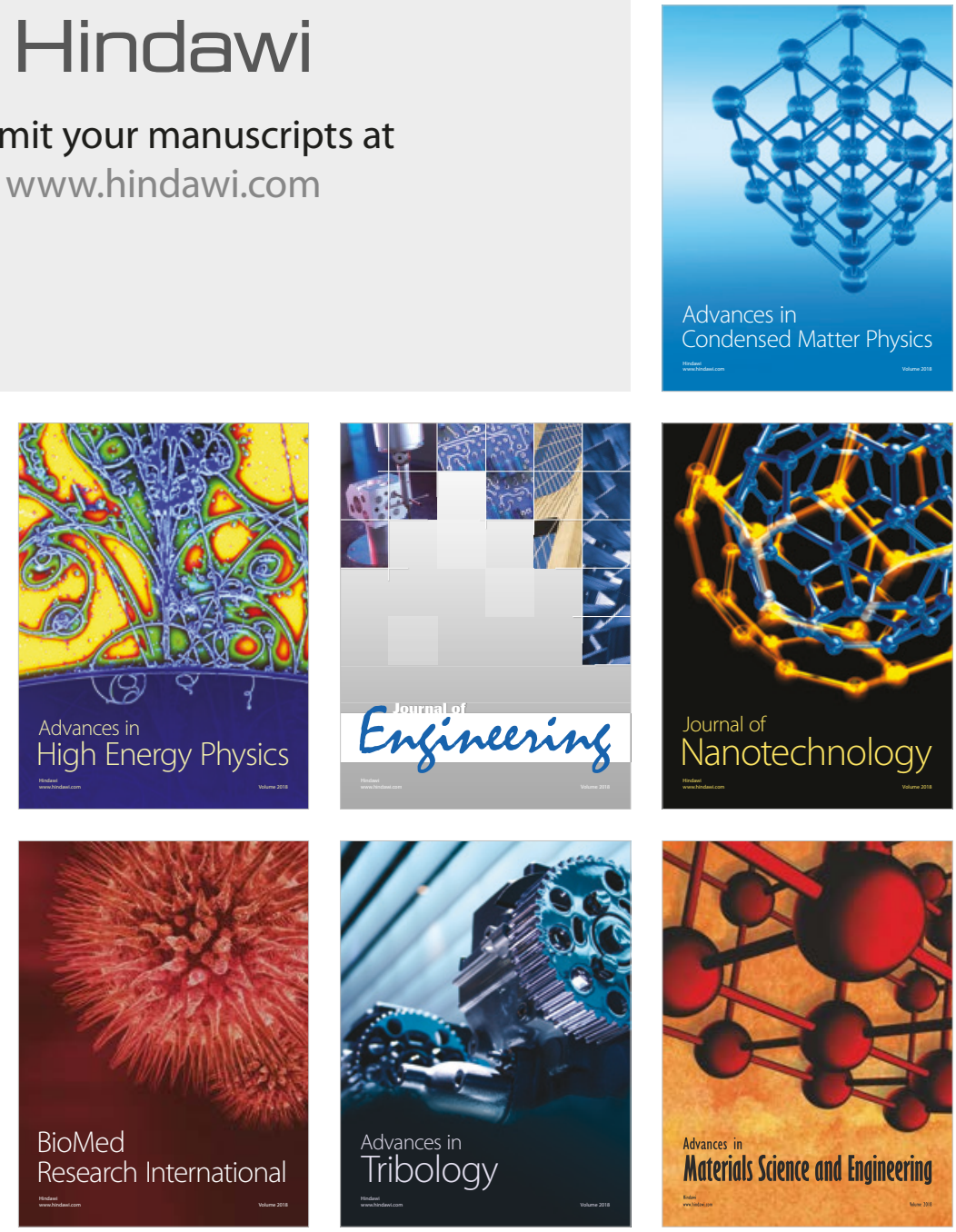